Developmental Biology of Gastrointestinal Hormones 


\section{Endocrine Development}

\section{Vol. 32}

Series Editor

P.-E. Mullis Bern 


\section{Developmental Biology of Gastrointestinal Hormones}

Volume Editors

Martin Wabitsch UIm

Carsten Posovszky Ulm

54 figures, 38 in color, and 14 tables, 2017

\footnotetext{
A 1 C Basel · Freiburg · Paris · London - New York · Chennai · New Delhi . 
Endocrine Development

Founded 1999 by Martin O. Savage, London

Martin Wabitsch, MD, PhD

Carsten Posovszky, MD, PhD

Division of Pediatric Endocrinology and Diabetes

Interdisciplinary Obesity Unit

Department of Pediatrics and Adolescent

Paediatric Gastroenterology and Nutrition

Department of Pediatrics and Adolescent

Medicine

University of Ulm

Ulm (Germany)

Medicine

University Medical Center UIm

Ulm (Germany)

Library of Congress Cataloging-in-Publication Data

Names: ESPE Advanced Seminar in Developmental Endocrinology (10th : 2016 :

Ulm, Germany), author. |Wabitsch, Martin, editor. | Posovszky, Carsten,

editor. | European Society for Paediatric Endocrinology, sponsoring body.

Title: Developmental biology of gastrointestinal hormones / volume editors,

Martin Wabitsch, Carsten Posovszky.

Other titles: Endocrine development ; v. 32. 1421-7082

Description: Basel ; New York : Karger, 2017. | Series: Endocrine

development, ISSN 1421-7082 ; vol. 32 |“10th ESPE Advanced Seminar in

Developmental Endocrinology, Ulm, June 3-4, 2016." | Includes

bibliographical references and indexes.

Identifiers: LCCN $2017032900 \mid$ ISBN 9783318059731 (hard cover : alk. paper) |

ISBN 9783318059748 (e-ISBN)

Subjects: | MESH: Gastrointestinal Hormones--physiology | Digestive

System--growth \& development | Pediatrics--methods | Congresses

Classification: LCC QP572.G35 | NLM WK 170 | DDC 612.3--dc23 LC record available at

https://lccn.loc.gov/2017032900

Bibliographic Indices. This publication is listed in bibliographic services, including Current Contents ${ }^{\circledR}$.

Disclaimer. The statements, opinions and data contained in this publication are solely those of the individual authors and contributors and not of the publisher and the editor(s). The appearance of advertisements in the book is not a warranty endorsement, or approval of the products or services advertised or of their effectiveness, quality or safety. The publisher and the editor(s) disclaim responsibility for any injury to persons or property resulting from any ideas, methods, instructions or products referred to in the content or advertisements.

Drug Dosage. The authors and the publisher have exerted every effort to ensure that drug selection and dosage set forth in this text are in accord with current recommendations and practice at the time of publication. However, in view of ongoing research, changes in government regulations, and the constant flow of information relating to drug therapy and drug reactions, the reader is urged to check the package insert for each drug for any change in indications and dosage and for added warnings and precautions. This is particularly important when the recommended agent is a new and/or infrequently employed drug.

All rights reserved. No part of this publication may be translated into other languages, reproduced or utilized in any form or by any means electronic or mechanical, including photocopying, recording, microcopying, or by any information storage and retrieval system, without permission in writing from the publisher.

(c) Copyright 2017 by S. Karger AG, P.O. Box, CH-4009 Basel (Switzerland)

www.karger.com

Printed on acid-free and non-aging paper (ISO 9706)

ISSN 1421-7082

e-ISSN 1662-2979

ISBN 978-3-318-05973-1

e-ISBN 978-3-318-05974-8 


\section{Dedication}

This volume is dedicated to

Professor Dr. Primus-Eugen Mullis

(November 11, 1954 - January 12, 2016)

in appreciation of his enthusiasm for paediatric endocrinology, his encouraging anima and his honest amity.

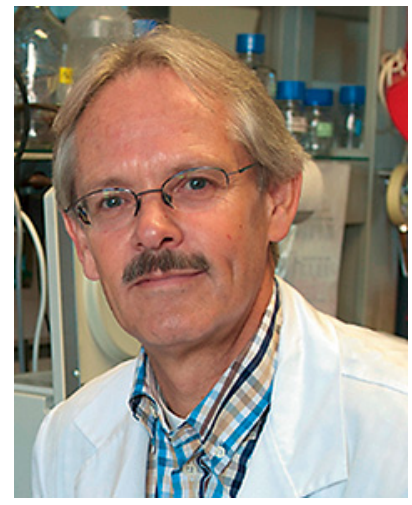

Martin Wabitsch 


\section{European Society of Paediatric Endocrinology Advanced Seminar in Developmental Endocrinology}

Endocrine Development Vol. 32, 2017

Developmental Biology of Gastrointestinal Hormones

10th ESPE Advanced Seminar in Developmental Endocrinology, UIm,

June 3-4, 2016

Editors: M. Wabitsch, C. Posovszky (UIm)

Hormone Research in Paediatrics Vol. 86, No. 4, 2016

Endocrine Disruptors and Child Health

9th ESPE Advanced Seminar in Developmental Endocrinology, Rome, May 2015

Editors: S. Cianfarani (Rome); O. Söder (Stockholm)

Endocrine Development Vol. 23, 2012

Developmental Biology of GH Secretion, Growth and Treatment

6th ESPE Advanced Seminar in Developmental Endocrinology, Bern, May 2012

Editor: P.-E. Mullis (Bern)

Endocrine Development Vol. 21, 2011

Cartilage and Bone Development and Its Disorders

4th ESPE Advanced Seminar in Developmental Endocrinology, Stockholm,

June-July 2010

Editors: O. Nilsson, L. Sävendahl (Stockholm)

Endocrine Development Vol. 19, 2010

Adipose Tissue Development from Animal Models to Clinical Conditions

3rd ESPE Advanced Seminar in Developmental Endocrinology, Paris, March 2009

Editors: C. Levy-Marchal (Paris); L. Pénicaud (Dijon)

Endocrine Development Vol. 12, 2007

Development of the Pancreas and Neonatal Diabetes

1st ESPE Advanced Seminar in Developmental Endocrinology, Paris, May 2007

Editors: R. Scharfmann (Paris); J.P.H. Shield (Bristol) 


\section{Contents}

VIII Foreword

Clayton, P.E. (Manchester)

IX Preface

Wabitsch, M.; Posovszky, C. (UIm)

1 Gastrointestinal Hormones Induced the Birth of Endocrinology

Wabitsch, M. (Ulm)

8 The Changing Concept of Gut Endocrinology

Rehfeld, J.F. (Copenhagen)

20 Development and Anatomy of the Enteroendocrine System in Humans

Posovszky, C. (Ulm)

38 Incretins and Their Endocrine and Metabolic Functions

Seufert, J. (Freiburg im Breisgau)

49 Role of Incretin Hormones in Bowel Diseases

Zietek, T.; Waldschmitt, N.; Rath, E. (Freising)

74 Ghrelin and Growth

Perchard, R.; Clayton, P.E. (Manchester)

87 Development of Sweet Taste Perception: Implications for Artificial Sweetener Use

Sylvetsky, A.C. (Washington, DC/Bethesda, MD); Conway, E.M.; Malhotra, S.;

Rother, K.I. (Bethesda, MD)

100 Just a Gut Feeling: Central Nervous Effects of Peripheral Gastrointestinal Hormones

Roth, C.L. (Seattle, WA); Doyle, R.P. (Syracuse, NY)

124 Gastrointestinal Endocrinology in Bariatric Surgery

Wabitsch, M. (UIm)

139 Enteroendocrine Cells: Metabolic Relays between Microbes and Their Host

Plovier, H.; Cani, P.D. (Brussels)

165 Treatment of Diabetes and Obesity by Rationally Designed Peptide Agonists Functioning at Multiple Metabolic Receptors

Khajavi, N.; Biebermann, H. (Berlin); Tschöp, M. (Munich); DiMarchi, R. (Bloomington, IN)

183 Author Index

184 Subject Index 


\section{Foreword}

The seminar series "ESPE Advanced Seminar in Developmental Endocrinology" was introduced in 2007 to provide members with an opportunity to explore the science behind the developmental aspects of endocrinology, topics that are not always covered in depth in the annual meeting or at our ESPE Schools. Since its commencement, three meetings have been held in France, two each in Sweden, Switzerland and Rome. The 2016 meeting was held in Germany. The attendees of this meeting came from 13 different countries, mainly in Europe and also from the USA and Israel, emphasising the appeal for such a meeting.

In recent years, our knowledge about gastrointestinal hormones and the multiplicity of their actions have advanced significantly. The gastrointestinal tract is the largest endocrine organ in the human body, and therefore endocrinologists need to understand its significance. The programme ranged from basic mechanisms through to clinical relevance and therapeutic potential. There was ample opportunity for discussion and networking during the meeting, the latter being an important aspect of focused meetings such as this. To capture all the data presented, each speaker has generated a chapter based on their presentation, and I do hope you will enjoy reading about the intricacies of gut hormones.

Martin Wabitsch and his team did a fantastic job in organising the meeting, which will be the last in this series. However, we recognise how important such meetings are and therefore the ESPE Science Committee is now going to host "ESPE Science Symposia," capturing the essence of this Seminar series, by gathering pediatricians in endocrinology and researchers in basic science on a specific topic to track the progress in fundamental science related to Pediatric Endocrinology and its potential application in clinical practice.

Peter E. Clayton, Manchester Secretary-General ESPE 


\section{Preface}

The interest on gastrointestinal endocrinology among physicians and scientists is on the rise. The gut not only represents the largest endocrine organ of the human body, but is also profoundly involved in the control of metabolism through peptide hormones. Therefore, gastrointestinal hormones act via autocrine, paracrine, and classical endocrine pathways and regulate, for example, digestion, hunger, and satiety. Furthermore, they are important regulators of growth, weight, and metabolism as well as mood and behavior.

Recent developments have led to new diagnostic and therapeutic tools and allowed the development of new pharmacological interventions, which use or mimic the effects and ways of action of gastrointestinal hormones.

Physicians and scientists in the field of pediatric endocrinology and diabetes as well as in pediatric gastroenterology, require an in-depth understanding of the factors controlling differentiation, gene expression, hormone secretion, and function to deal with the challenges in the field of gastrointestinal endocrinology in the future. To meet the complying needs, the 10th Advanced Seminar on Developmental Endocrinology, which took place in the city of Ulm, Germany, on the 3rd and 4th of June, 2016 discussed the topic "Developmental Biology of Gastrointestinal Hormones." The scientific program attracted participants and speakers from 13 European countries and the US. Participants and speakers discussed extensively recent developments in the field of gastrointestinal endocrinology with respect to child health.

Following the good tradition of the ESPE Seminars on Developmental Endocrinology and also the express wish of participants, we invited speakers to write up a contemporary review on the topic of their presentation for a new volume of the Karger series "Endocrine Development".

We thank the authors for their valuable contributions, making this volume a stateof-the-art document on this new and exciting subspecialty in pediatric endocrinology.

Martin Wabitsch, Ulm

Carsten Posovszky, Ulm 
